\section{Poder Legislativo e Poder Regulamentar na Constituição Moçambicana de 30 de Novembro de 1990}

\author{
GILLES CISTAC
}

Professor de Direito Público

Faculdade de Direito. Universidade Eduardo Mondlane, Moçambique*

O estudo do regime juridico do acto administrativo necessita de ser interrogado, no quadro do procedimento de elaboração do acto, sobre 0 dominio em que uma autoridade administrativa pode intervir ${ }^{1}$. É uma das questões mais clássicas do direito administrativo que tem consequências juridicas sobre a validade do acto. Com queito, o agente que adoptaria um acto fora do seu dominio de competência veria o seu acto manchado de irregularidade juridica ${ }^{2}$ Isto que dizer que uma autoridade administrativa só pode adoptar um acto no quadro dos poderes que lhe são investidos, ou mais precisamente, da competência que lhe é atribuida ${ }^{3}$. Quanto ao número de irregularidades que podem ser levantadas contra um acto desta natureza, em direito ad ministrativo francês, figura evidentemente, 0 vicio de incompetência "ratione materiae" devido ao objecto do seu acto resultante do facto que acto adoptado intrometer-se-ia no dominio do poder legislativo ${ }^{4}$, ou, em direito português, vicio de usurpação de poder ${ }^{5}$

A questão da delimitação da intervenção do poder regulamentar tem, pois, incidências práticas importantes sobre a capacidade de acção deste poder.

O objecto do presente estudo é proceder uma tentativa de avaliação da capacidade de intervenção do poder regulamentar moçambicano. Mas, uma investigação desta natureza, não pode fazer economia da delimitação deste pode em relação ao poder legislativo; tanto é verdade que só se pode definir em relação a outrem, ou pelo menos em relação a um terceiro, o que nos

fornece a dimensão da existência do que constitui objecto de definição. Consequentemente, a delimitação do dominio de intervenção do pode legislativo opera automaticamente a delimitação do dominio de intervenção do poder regulamentar e vice-versa.

Nalguns sistemas jurídicos, tendo em conta a sua importância, algumas matérias estão reservadas ao legislador; elas dependem da competência legislativa. É o caso da Constituição francesa de 4 de Outubro de $1958^{6}$ De 1789 a 1958 pode-se observar o carácter ilimitado do dominio legislativo ${ }^{7} \mathrm{~A}$ lei pode intervir em todas as materias. Com a Constituição de 1958, ela passa a ser delimitada pelo artigo 34. Este texto enumera limitativamente as matérias para as quais o legislador é competente; ele distingue. por um lado, as matérias em que a lei "estabelece os regulamentos" - por exemplo, os direitos civicos e as garantias fundamentais concedidas aos cidadãos para o exercício das liberdades públicas $-\mathrm{e}$, por outro lado, aquelas em que a lei só pode "determinar os principios fundamentais" - por exemplo, a organização geral da defesa nacional, o regime da propriedade, o direito trabalhista. Neste dominio da lei, o legislador è o único mestre: mas, ao mesmo tempo, ele é prisioneiro: ele só é competente para estatuir sobre as materias que the sio reservadas, sendo incompetente para todas as outras. Segundo 0 artigo 37, "As outras matérias, fora do domínio da lei terão carácter regulamentar", e dependem, pois, segundo o artigo 21, do PrimeiroMinistro ${ }^{8}$.

*Professor francês correspondente do grupo de pesquisas coordenado pela Prof ${ }^{\text {t }}$ Claudia Lima Marques, Dept ${ }^{\circ}$ de Direito Público e Filosofia do Direito, atualmente em missão de cooperação em Moçambique.
O dominio do regulamento deduz-se, ao contrário, da enumeração das matérias legislativas indicadas pelo artigo 34: ele só é limitado por esta enumeração. O resultado é: a autoridade regulamentar possui teoricamente a competência de direito comun, no que concerne à elaboração das regras gerais, exercendo o legislador apenas uma competência de atribuição; que em principio, nas matérias regulamentares, o governo exerce uma competência não condicionaverno exerce uma competência não condicionada e estatui com uma liberdade análoga a do
legislador; este poder regulamentar autónomo deixa substituir o seu campo de acção tradicional definido pela "execução das leis": como na época anterior, compete-lhe, em matéria legislativa, adoptar os regulamentos que podem exigir a aplicação dos textos aprovados pelo Parlamento; mas ele só exerce, neste caso, uma competência subordinada e limitada. Para além da personalidade dos conceptores da Constituição de 1958, particularmente o General De Gaulle, Michel Debré e René Capitant ${ }^{9}$, pode observarse a vontade de "racionalizar" o parlamentarismo, prevendo na Constituição uma sẻrie de disposiçōes tendentes a evitar que os ministros sejam importunados pelos deputados, e a permitir que o Primeiro-Ministro obtenha os meios para governar. A limitação do dominio legislativo figura entre aquelas disposiçōes ${ }^{10}$. Por outras palavras, e para citar a expressão de Bernard Chantebout, trata-se "da destruição da hegemonia parlamentar"11.

0 que é que acontece na Constituição moçambicana? ${ }^{12}$

Em primeiro lugar, pode-se observar que a Constituição de 30 de Novembro de 1990 parece atribuir um dominio de competência material ilimitado ao poder legislativo. Com efeito, o artigo 133 da Constituição precisa: "A Assembleia da República determina as normas que regem o funcionamento do Estado e a vida económica e social através de leis e deliberações de carácter genérico"; do mesmo modo, o artigo 135 dispõe: "l. Compete à Assembleia da República legislar sobre as questões básicas da politica interna e externa do pais". Mesmo se o poder constituinte moçambicano apresenta nos números 2 e 3 deste artigo 135 uma lista enumerativa do dominio de intervenção do legislador, o poder constituinte moçambicano emprega 0 advérbio "nomeadamente". o que quer dizer, se empregarmos sinónimos, particularmente, especialmente, mormente ${ }^{13}$, com o objectivo de atrair a atenção sobre vários assuntos particulares do domínio de intervenção mais geral do legislador.

Em outras palavras, a enumeração dada é puramente indicativa e o legislador pode intervir sem limites sobre todas as "questões (..) da politica interna e externa", do ponto de vista do seu dominio material de intervenção. Todavia, seu dominio material de intervenção. Todavia, deveremos interpretar a ação do poder regulamentar na Constituição moçambicana unicaverno só adopta regulamentos para a execução das leis: o que implicaria que ele só pode agir num determinado dominio quando o próprio legislador já tenha intervido nesse dominio? Nesta perspectiva, o governo dispõe apenas de uma competência residual: ele fixa os pontos que 0 legislador não precisou devidamente. A realidade moçambicana é mais complexa, ele coloca alguns limites de accão ao legislador (I) e atribui os meios de acça importantes, sem no entanto atribuir-lhe um poder para editar "regulamentos autónomos" no sentido do direi to constitucional e administrativo francês (II).

\section{I - OS LIMITES CONSTITUCIONAIS DO} DOMÍNIO DE ACÇÃO DO LEGISLADOR

A análise do próprio texto constitucional e da prática legislativa na matéria, permite operar uma distinção entre os limites de natureza estrutural (A) e os limites de natureza temporal (B).

\section{A - Os Limites Estruturais}

a) 0 número 2 do artigo 133 da Constituição define: "A Assembleia da República deter. mina as normas que regem o funcionamento do Estado e a vida económica e social através de leis e deliberações de carácter genérico"14.

Em primeiro lugar, é necessário analisar a terminologia empregue neste artigo para qualificar os actos legislativos da Assembleia da República (1), antes de se interrogar sobre a incidência do carácter genérico atribuido a estes mesmos actos (2).

O número 2 do artigo 133 emprega os termos "leis" e "deliberaçōes" para qualificar os 
actos legislativos da Assembleia da República. Se o termo "leis" está suficientemente delimitado para não necessitar de desenvolvimentos substanciais, ao contrário, o termo "delibera ções" pode suscitar algumas perguntas.

A generalidade do conteúdo da expressão disprove-lhe de toda a performância. Com efeito na própria origem, o vocábulo é sinónimo de "acto (que) dimana de um órgão colegial"15; próprio termo pode designar a vontade de toda a pessoa colectiva ${ }^{16}$, e, por isso, não tem o rigor e a precisão terminológica acabado do termo d "leis"17. Segundo a definição acima mencionada, a lei é também uma deliberação, o que em algumas hipóteses só tem um efeito de redundância sem consequências práticas reais se se considerar o termo "deliberacão" no seu sentido original e comun ${ }^{18}$. Contudo, esta falta de precisão poderia ter sido evitada se se tivesse recorrido à nomenclatura estabelecida pelo ar tigo 141 da Constituição. Este último, estả redigido da seguinte maneira: "Os actos legislativos da Assembleia da República assumem a forma de lei $e$ as demais deliberaçōes revestem a forma de resolução e são publicados no Boletim da República". Do ponto de vista lexicológico, o artigo 141 introduz nova terminologia ao designar por "resolução" os outros tipos de deliberações legislativas. Assim, seria mais judicioso substituir o termo "deliberaçōes" pelo termo "re solução", para evitar algumas confusões ou re nologica só desloca o problema para o terren da definição do termo de "resolução". Segundo uma definição geralmente aceite, entende-se po resolução "certas deliberaçōes de vários órgãos de soberania"19. 0 texto constitucional, embora se refira às resoluçōes, não fornece nenhuma noção de resolução. Neste aspecto, poderiamo tornar nossas as conclusões de $\mathrm{M}$. Gomes $\mathrm{Ca}$ notilho sobre a prática legislativa portuguesa das resoluçōes, e apoiar que ela "apenas se limita a seguir a prática constitucional que considera as resoluçōes como uma forma de as assembleias (...) manifestarem as suas intenções e tomarem decisōes, sem que seja necessário adoptar um acto normativo (lei, decreto-lei, decreto-regulamentar)"20.

A doutrina portuguesa apresenta então a re solução como um acto legislativo não normativo. Contudo, esta apresentação foi criticada pela doutrina, pela própria existência de resoluçōes que "têm um sentido normativo evidente"ml; temos a cemplo, as resoluçozes da Assembleia da República referentes à não ratifica ção de decretos-lei legislativos regionais ${ }^{22}$, as resoluções respeitantes à suspensão da execução dos decretos-lei e decretos legislativos regionais ${ }^{23}$, as resoluções da comissão permanente da Assembleia República de autorização da de claraçāo de guerra e exercício da paz pelo Presidente da República ${ }^{24}$, as resoluções de aprovação de tratados ${ }^{25}$. No direito constitucional português, constata-se então a existência de actos normativos, que não são leis, adoptados pelo Parlamento. Do ponto de vista prático, qual é o interesse de manter essa distinção? Podem identificar-se dois que não estão isentos de $O$ primeiro baseia-se no facto de, do ponto de vista formal, a resolução não ser alvo de promulgação da parte do Presidente da Repúbli$\mathrm{ca}^{26} ; 0$ segundo reside no facto de as resoluçōes não estarem sujeitas ao controle jurisdicional ${ }^{27}$

Da própria confissão da doutrina portuguesa, "o problema da natureza juridica das resoluções continua a suscitar discussões, devendo confessar-se que, até ao momento, não há nenhuma elucidação clara do conceito" 28

$\mathrm{O}$ direito moçambicano adopta uma posição intermediária. Nalguns aspectos, ele adopta um posição comparável ao direito constitucional português, parecendo dissociar-se noutros. Um da República permitir-nos-á apresentar a práica do legislador moçambicano na matéria.

Do ponto de vista dos actos adoptados, a actividade do legislador moçambicano pode constituir objecto de uma divisão entre os actos legislativos, no sentido restrito do termo, e os actos que não o são.

Com efeito, como as autoridades administrativas podem adoptar actos que não são administrativos ${ }^{29}$, o legislador em geral ${ }^{30}$, e o legisla dor moçambicano em particular, pode adoptar actos que não são de naturaza legislativa. Aliás, o texto do artigo 141 da Constituição, convidanos a fazer tal distincão. Com efeito, se actos do legislador fossem actos legisl porquê sacrificar-se a utilizar o epiteto "legislativos" para qualificar tais actos. O termo "ac tos" seria suficiente. Se o constituinte moçambicano sacrificou-se em qualificar os actos adoptados pelo poder legislativo como "legislativos" è porque a necessidade de distinguir tais actos dos actos que têm o mesmo actor, mas que se distinguiam em diversos pontos, se fazia sentir, essencialmente, do ponto de vista normativo.

Na primeira categoria, podem colocar-se a lei e a resolução, na segunda a moção ${ }^{31}$.

A principal dificuldade provém essencialmente do conteúdo do termo "resolução", pelos mote do conteudo do termo "resolução", pelos mo-
tivos aduzidos anteriormente. Com efeito, a resolução pode ser normativa - caso da resolução através da qual a Assembleia da República ratifica os tratados internacionais ${ }^{32}$, em virtude do alinea k) do número 2 do artigo 135 da Constituição $0^{33}$ - ou não normativa - no caso de resoluçōes que designam os deputados da lista de suplentes da Assembleia da República, para garantirem a substituição de deputados faleci$\operatorname{dos}^{34}$ ou das resoluções inerentes à apreciação da acção politica do governo ${ }^{35}$. Nestas diferentes hipóteses, se houver uma manifestação de normas de conduta, não há manifestação de um poder normador objectivo. Assim, um acto le gislativo pode ter natureza não normativa. A distinção pode operar-se segundo o critério dos efeitos do acto em causa: criador ou não de direito. vontade ou ausência de vontade de modificar ordenamento juridico.

Assim, podem observar-se três tipos de actos tomados pelo poder legislativo no quadro do artigo 141 da Constituição: a lei, a resolução normativa e a resolução não normativa.

Neste estado da análise, colocam-se dua questões. A primeira é relativa à possivel class ficação de tais actos, a segunda abarca a diferença real entre a resolução não normativa e moção.

A primeira questão que é possivel formular relativa à diferença entre a lei e a resolução normativa. Para diferenciá-las, não se pode basea na diferença sobre os efeitos, pois, na realidade, os dois actos são normativos. Só as podemos distinguir dum ponto de vista formal: uma a lei, é promulgada pelo Presidente da Repúbli$\mathrm{ca}^{36}$, a outra, a resoluçāo, conforme a prática constitucional portuguesa ${ }^{37}$, não é objecto de nenhum processo de promulgação. Nestas connenhum processo de promulgação. Nestas con-
diçōes, mantendo a terminologia estabelecida dições, mantendo a terminologia estabelecida
pelo artigo 141 da Constituição, porque não modificar a pratica legislativa e reservar à lei a forma do acto legislativo normador? Nesta hipótese 0 acto de ratificacão seria uma lei e não uma resolução, e, por via de consequência, reservar a àrea da actividade legislativa não normativa à resolução? Esta tipologia baseada sobre a normactividade do acto, relacionada com uma forma juridica unica que the seria atribuida, teria o mérito de evitar a dificuldade onipresente em direito constitucional português, que é de saber se uma resolução é um acto normativo ou não $0^{38}$.

A segunda refere-se a possivel diferença entre a resolução não normativa a moção, e sobre o interesse em manter tal distinção. Com efeito, que diferença pode existir entre uma moção e uma resolução normativa?

Se nos colocarmos do ponto de vista formal nos dois casos, o acto é "aprovado" pela Assembleia da República e assinado pelo Presidente da Assembleia.

Se nos situarmos no plano do conteúdo, dificilmente podemos identificar uma diferença fundamental entre os dois tipos de actos. Na realidade que dif tuaça em que a da Rén ter ção, apresentado por Sua Excelência o Senhor Presidente da República e examinado os relatórios do Primeiro-Ministro e do Ministro das Finanças (...) Decide: 1. Agradecer a deferência de Sua Excelência o Presidente da República (...) prestando uma informação ampla e valiosa contendo as normas essenciais para o prosseguimento da acção estatal. 2. Exprimir o seu apreço e louvor (...) ao Conselho de Ministros e especialmente ao Primeiro-Ministro (...), pela dedicação e competência expressa pelo governo" ${ }^{39}$, e a situação em que "A Assembleia da República (...) tendo apreciado a informação do Governo sobre a implementação do Acordo Geral de Paz (...) decide: 2. Enaltecer a acção do Presidente da República (...), na defesa da aplicação do espirito e da letra do Acordo de Roma; (...) 7. Apoiar o Governo da República de Moçambique no sentido de prosseguir consequentemente nas medidas que assegurem a unidade nacional e a administração, ordem e a tranquilidade públicas, no quadro da Constituição da República, e da implementação do Acordo Geral de Paz"${ }^{n 0}$

Nestas duas situações, é dificil identificar elementos objectivos de diferenciação, senão 0 
carácter mais solene da segunda situação, em relação à primeira; será que por isso ela mereceria, do ponto de vista da forma, que se the introduza um novo conceito de fundo discutivel para qualificá-la?

No presente caso, o constituinte moçambicano poderia ter feito a economia de um dos termos (moção ou resolução), para qualificar os actos não normativos do legislador.

Como já o havíamos assinalado precedentemente, o constituinte moçambicano adoptou, em alguns pontos, uma posição comparável ao direito e à prática constitucional portuguesa, essencialmente na qualificação dos actos adoptados pelo poder legislativo e a ausência de promulgação das resoluções adoptadas pela Assembleia da República. Contudo, quanto ao regime juridico de alguns destes actos, ela parece dissociar-se.

Atardar-nos-emos essencialmente no regime das resoluções. Por um lado, no direito constitucional português, a resolução caracteriza-se pela desnecessidade de promulgação pelo Presidente da República, e por outro lado, pela ausência de um controle jurisdicional ${ }^{41}$.

Sobre o primeiro aspecto, pudèmos julgar a identidade do regime entre 0 direito constitucional moçambicano e o direito constitucional português. No que concerne ao segundo, convém chamar a atenção sobre a originalidade do direito constitucional moçambicano que admite o controle da constitucionalidade das resoluçōes, pelo menos no seu principio. Com efeito, 0 artigo 181 da Constituição moçambicana, referente às competências do Conselho Constitucional, dispôe o seguinte: "1. Compete ao Conselho Constitucional: a) apreciar e declarar a inconstitucionalidade e ilegalidade dos actos legislativos (...)". Nos desenvolvimentos anteriores, pudèmos medir o conteúdo do vocábulo "actos legislativos" que engloba os actos integrados no artigo 141 da Constituição, isto é, as leis e as resoluções. Então, podemos notar aqui um progresso no controle da legalidade dos actos do Parlamento, exigido pelo princípio da constitucionalidade no Estado de direito 42 .

2. Convém, desde já, interrogar-se sobre a natureza e 0 alcance do "carácter genérico" ${ }^{43}$ atribuido a estes actos diversos actos. Podemos fazer duas interpretações da expressão "carácter genérico". Por um lado, pode pensar-se que a expressão refere-se exclusivamente a "deliberacōes" ou, por outro lado que a expressão se reere às "leis" e às "deliberaçōes".

No primeiro caso, pode deduzir-se que só as deliberações devem ter um carácter genérico, $\mathrm{e}$ que, por consequência, a lei possa regulamentar detalhadamente um dominio material da sua competência, noutra hipótese, a lei e as delibecarácter genérico, o que significa que tem um carácter geral. 0 acto adoptado pela Assembleia da República não seria detalhadamente regulamentado no domínio considerado, mas somente fixaria as regras gerais da matéria ou os seus grandes principios. Por outras palavras, o legislador só pode colocar normas de principios; é-lhe proibido ir mais longe.

Resta o problema da sanção, no caso em que uma lei regeria em pormenor uma matéria em que ela só possui o poder para definir normas genéricas. Para resolver o diferendo, conhece-se o órgão competente que é o Conselho Constitucional ${ }^{44}$, mas hoje, não temos nenhuma resposta para este assunto, por falta de Conselho Constitucional ${ }^{45}$

b) Outro limite do carácter formalmente ilimitado do dominio legislativo, reside na natureza dos problemas tratados. $O$ número 1 do artigo 135 da Constituição, precisa que "compete à Assembleia da República legislar sobre questões básicas da politica interna e externa do pais"46. "m outros termos, o legislador mocambicano so poute legislar sobre pode legislar sobre "questos basicas". Neste artigo, tanto como no artigo 133, o poder constituinte moçambicano emprega uma terminologia de natureza geral e abstrata. O termo "básicas", na expressão "questões bảsicas", è empregue no seu significado comun que é "fundamenal". Nesta fase da análise, podemos fazer duas observaçōes.

A primeira é referente à semelhança dos artigos 133 e 135 da Constituição. Poderiamos ter a tendência de dar uma interpretação mais ampla ao termo "genérico", que não só se aplicaria às "deliberações" como também às "leis".

A segunda observação ė sobre a limitação do dominio material de intervenção do legislador. Não se trata de uma limitação de natureza do dominio de intervenção propriamente dito, porque o legislador pode intervir sobre todas as "questões (...) da politica interna e externa do pais", mas uma limitação do grau de intervenção do legislador.

Ele só pode intervir sobre "questões básicas" da politica interna e externa do pais, o que que dizer, só sobre as questões fundamentais destas politicas. $\mathrm{O}$ verdadeiro problema nestas cir cunstâncias é o problema da definição do conteúdo do termo "básicas"; o que é uma questão básica? Coloca-se um problema de qualificação susceptivel de diferendo, porque ele pode influenciar as delimitaçōes das competências entre o legislador e o poder regulamentar. Aqui, também se pode pensar que o Conselho Constituc onal terá um papel importante a desempenhar.

\section{B - Os Limites Temporais}

Os limites temporais da acção do poder legislativo, são outro tipo de limites. Com efeito ao abrigo do artigo 139 da Constituição moçambicana ${ }^{47}$, "A Assembleia da República reúne-se ordinariamente duas vezes por ano e extraordinariamente sempre que a sua convocação for requerida pelo Presidente da Repüblica, pela $\mathrm{Co}$ missão Permanente da Assembleia da Repúblca ou por um terço, pelo menos, dos deputados da Assembleia da República”. Noutros termos, a Assembleia da República não se reúne de maneira permanente ${ }^{48}$. Ela só pode legislar durante as sessōes ordinárias ou extraordinárias fora do tempo de sessão, o processo de produção das normas legislativas está parado. A situação não é chocante: é o caso do regime comun da maior parte dos parlamentos do mund $0^{49}$ Contudo, ela devia ser mencionada como um limite objectivo da actividade do legislador moçambicano.

Da argumentação apresentada, salienta-se 0 facto de o domínio de intervenção do legislado moçambicano ser um dominio "assinado". Dai convém interrogar-se sobre o dominio de intervenção do poder regulamentar.

\section{II - O DOMÍNIO DE INTERVENÇÃO DO PODER REGULAMENTA R ${ }^{50}$}

Face a estas limitações constitucionais objectivas no domínio da acção do poder legislativo, qual è o dominio de intervenção do pode regulamentar?
Por outro lado, podemos tentar delimitar 0 dominio de acção do poder regulamentar, em função da natureza deste poder: poder regulamentar complementar ou executivo, no sentido literal do termo, e, por outro lado, poder regulamentar autónomo, nas suas relaçóes com a lei ${ }^{51}$. No entanto, a situação analisada está tão confundida que seria temerário tentar distinguir os dois pontos de vista. No plano metodológico, adoptaremos o procedimento seguinte: tomaremos como referência as relações susceptiveis de se estabelecerem entre a lei e o regulamento, afim de determinar em cada caso a natureza do poder regulamentar em causa.

Podemos imaginar três situaçōes: Uma lei precede a acção do poder regulamentar (A), a ausência de textos legislativos que regulamentam a matéria (B), e o caso em que o governo adopta um regulamento em qualquer matéria e o legislador decide intervir na regulamentação desta matéria (C)

\section{A - Primeira Situação: Uma Lei Precede a} Acção do Poder Regulamentar

Nesta hipótese, podem imaginar-se várias situações, em função da forma e do conteúdo do texto legislativo.

\section{Primeiro Caso}

A lei ou a deliberação tem um carácter genérico e é relativa a uma questão básica de politica interna e externa do país.

Neste caso, pode pensar-se que estamos perante 0 caso clássico do poder regulamentar, no sentido do poder executivo ${ }^{52}$ das leis que só têm ao seu cargo executar as leis ${ }^{53}$, através de regulamentos de aplicação complementares ou de execuçã $0^{54}$

No quadro desta missão, o poder regulamentar pode tomar todas as medidas exigidas pela aplicação da lei. Pode-se procurar na Constituição, um fundamento formal desta actividade juridica do Conselho de Ministros. Ao abrigo do número 1 do artigo 152 "O Conselho de Ministros assegura a administração do país, garante a integridade territorial, vela pela ordem pública e pela segurança e estabilidade dos cidadãos, promove o desenvolvimento e consolida a legalidade e realiza a politica exterior do pais". As 
expressōes "O Conselho de Ministros assegura a administração do pais" e "consolida a legalidade", podem ser interpretadas como indices dade", podem ser interpretadas como indices
deste poder de execução das leis. Também se pode considerar que a missão de execução das leis é uma actividade inerente ao poder executivo, sobre o fundamento dos próprios poderes implicitos.

\section{Segundo Caso}

A lei ou a deliberação não tem nenhum carácter genérico e/ou não é relativa a uma questão básica de politica interna e externa do pais. Podem imaginar-se três hipóteses:

2.1. A primeira pode situar-se durante a discussão da lei ou da deliberação perante a Assembleia da República, quando a iniciativa da lei pertence às comissóes da Assembleia da Relei pertence às comissoes da Assembleia da Re-
pública ou aos Deputados ${ }^{55}$, o Presidente da pública ou aos Deputados
República, o Primeiro-Ministro, ou o Procurador Geral da República, podem considerar que algumas disposiçōes deste texto não são do dominio legislativo porque não têm um carácter genérico e/ou não colocam sobre questões básicas de politica interna e externa do pais. Nesta hipótese, cabe ao Presidente da Assembleia da República estatuir: ou então, ele pede o parecer do Governo e decide que as disposições litigiosas são do dominio regulamentar, ou ele considera que as disposições litigiosas são da competência da Assembleia da República, e, neste caso, o seu exame é suspenso provisoriamente. Teoricamente, este tipo de diferendo é da comTeoricamente, este tipo de diferendo e da com-
petência do Conselho Constitucional, em virtude dos artigos 180 e 181 da Constituição. Com efeito, o artigo 180 da Constituição precisa que "O Conselho Constitucional é um órgão de competência especializada no dominio das questões juridico-constitucionais" e a alinea b) do número 1 do artigo 181 dispõe " 1 . Compete ao Consetho Constitucional: b) dirimir conflitos de competência entre os órgãos de soberania". Nesta eventualidade, as autoridades acima mencionadas poderão recorrer ao Conselho Constitucional ${ }^{56}$ que deverá estatuir sobre esta "questão juridico-constitucional" 57 .

Ele pode ter uma interpretação restrita dos termos "genérico" e "básicas" ou, pelo contrário, fazer uma interpretação extensiva destes termos; neste último caso, a lei poderia regulamentar os

mais pequenos detalhes do dominio material em causa.

2.2. A segunda hipótese de trabalho possivel, è a situação do texto legislativo votado, mas que ainda não está promulgado pelo Presidente da República ${ }^{58}$. A lei é uma instância de promulgação, mas ela parece quer para o Presidente da República, quer para o Primeiro-Ministro, quer para o Presidente da Assembleia da República ou quer para o Procurador Geral da Repúlica, que ela cont blica, que ela contem disposições inconstitucionais. Então, para estas personalidades, e ao abrigo dos artigos 180 e 181 da Constituição, é possivel recorrer ao Conselho Constitucional e pedir que ele declare toda ou uma parte da lei inconstitucional.

2.3. A terceira situação possivel é o caso em que uma lei foi aprovada e promulgada, mas 0 Governo apercebe-se que algumas destas disposiçōes apresentam um carácter regulamentar. Nesta situação, o Presidente da República, o Primeiro-Ministro ou o Procurador Geral da República, poderia recorrer ao Conselho Constitucional que decidiria em última instância, perante cada uma das disposiçoes da lei, se essa disposição é de n ela é de natureza legislativa. Nesta situação, o Conselho Constitucional poderia autorizar o Governo a abrogar ou a modificar as medidas, erradamente tomadas em forma de lei, por um acto regulamentar.

\section{B - Segunda Situação}

Há ausência de textos legislativos que regulamentam a matēria. A questão é a seguinte: 0 Governo pode intervir nestas matérias?

Pode dar-se uma resposta afirmativa a esta pergunta, por duas razōes: A primeira é simultâneamente de origem lógica e jurisprudencial; sendo a segunda de origem constitucional.

1. Com base numa célebre sentença do direito administrativo francês, pode-se apresentar este primeiro elemento de resposta: Sentenca do Conselho de Estado de 8 de Agosto de 1919 Labonne ${ }^{59}$. Em 1899, o Presidente da República francesa adopta um decreto para regulamen-

tar a circulação automóvel; aliás, o que constitui o primeiro código de estrada.

O senhor Labonne viu-se-lhe privado do seu "certificado de capacidade para a condução de veículos automóveis", o que significa, na linguagem atual, a sua carta de condução; este último contestava a competência do Presidente da República de intervir na matéria, porque a lei confiava esta competência às autoridades departamentais e municipais. 0 problema era pois de saber se o Presidente da República podia intervir, na ausência de uma habilitação legislativa. O Conselho de Estado rejeitou a argumentação do queixoso e reconheceu ao Chefe de Estado do queixoso e reconhece mentação. O Chefe de Estado tinha um poder próprio de política sobre o conjunto do território. Cabe, pois, ao Chefe do executivo assegurar a ordem pública ${ }^{60}$ sobre o conjunto do território, mesmo na ausência de qualquer disposição legislativa expressa. De facto, o Chefe do executivo detem um poder próprio de regulamentação, independentemente de toda delegação legislativa. Esta concepção foi confirmada pelo Conselho Constitucional francês, em $1987^{61}$, em que a alta jurisdição decidiu "que o artigo 34 da Constituição não retirou ao Chefe do Governo as atribuiçōes de policia geral que ele exercia anteriormente, em virtude dos seus próprios poderes e fora de toda habilitação legislativa". A transposição de toda hrincípio geral do direito administrativo frantal princípio geral do direito administrativo fran-
cês em direito administrativo moçambicano é tocês em direito administrativo moçambicano é to-
talmente admissivel para fundamentar uma intervenção do poder regulamentar nesta matéria. Assim, do nosso ponto de vista, o Governo moçambicano, na ausência de intervenção prévia do legislador, pode adoptar regulamentos da via do legislador, pode adoptar regulamentos da
sua propria iniciativa em materia de policia adsua própria iniciativa em matéria de policia ad-
ministrativa geral ou para assegurar o bom funministrativa geral ou para assegurar o bom fun
cionamento dos serviços colocados sob a sua autoridade. Por outras palavras, trata-se de assegurar as condiçōes necessárias para a continuidade da vida nacional, isto é, a manutenção da ordem pública e a bom desenrolar dos serviços públicos e isto independentemente das prescrições formais do legislador. Este argumento da "necessidade regulamentar" do poder executivo e a fortiori válido em casos de circunstâncias excepcionais (tempo de guerra) ${ }^{62}$.

\section{Os Argumentos Constitucionais Neste} Sentido

2.1. Antes de examinar o texto constitucional, convém assinalar que se considerarmos fun- dada a interpretação precedente relativa à definição e aos limites do dominio de accão do poder legislativo, podemos interrogar-nos para saber se a forma da norma de carácter genérico que é relativa a uma questão básica da política interna e externa do país, é da competência exclusiva do legislador.

$\mathrm{Na}$ Constituição moçambicana nada proibe o poder regulamentar de adoptar normas de ica interna e externa do país. Por um lado, os artigos 133 e 135 da Constituição não estabelecem uma competência exclusiva do legislado na utilização da forma da norma de um carác ter genérico sobre questões básicas da politica interna e externa do país. Do nosso ponto de vista ha uma verdadeira concorrência na escopoder legislativo e o poder regulamentar. Com efeito, nada impede ao poder regulamentar no âmbito do artigo 152 de adoptar normas com carácter genérico senão a habilitar tal ou ta ministro a adoptar diplomas ministeriais para assegurar a realização da norma geral e impessoal.

2.2. 0 artigo 152 estabelece claramente " 1 . o Conselho de Ministros assegura a administração do pais, garante a integridade territorial, vela pela ordem pública e pela segurança e estabilidade dos cidadãos, promove 0 desenvolvimento econômico, implementa a acção social do Estado, desenvolve e consolida a legalidade e realiza a politica exterior do país". Em primeiro lugar, pode-se realçar que em nenhuma ocasião o artigo 152 comporta o termo de lei que deixaria supor uma certa relação de subordinação no procedimento de produção normativa. A segunda observação é que o texto emprega os termos de "assegura" a administração do país, "vela" pela ordem pública, "promove" o desenvolvimento econômico, "implementa" a acção social do Estado, "desenvolve" e "consolida" a legalidade e "realiza" a politica exterior do pais. Todos os verbos estão no presente do indicativo, o que significa obrigacão de fazer. Nesta actividade material que se lhe impõe, o governo pode regulamentar por via de normas gerais e impessoais, e isto mesmo na ausência de uma lei. Tomemos o caso da ordem pública. O governo tem a obrigação de assegurar a ordem pública e isto em virtude do número 1 do artigo 152 e da ali- 
nea b) do número 1 do artigo 153 da Constituição. De um ponto de vista prático, se a necessidade de assegurar a ordem pública surge entre duas sessóes da Assembleia da República e que não haja nenhum texto legislativo no dominio em que o Governo quer ou deve regulamentar.

Que deve fazer o Governo ${ }^{63}$ ? Deveria esperar por uma lei que lhe habilitaria a intervir neste dominio: Deve-se interpretar o texto no sentido de dar-lhe a sua plena eficácia, o que quer dizer que há possibilidade, através do poder regulamentar, de intervir nestas matérias na ausência de uma regulamentação legislativa. Aqui, poderiamos tornar nossas as célebres conclusōes do comissário do Governo Romeu quando do Processo da "Société Immobilière de st Just" concesso da " a rçada, em direito administrativo francês, para ilustrar esta necessidade prática de ação do poder regulamentar: "É essência própria do papel da administração agir imediatamente e empregar a forca pública sem prazo nem procedimento, desde que 0 interesse imediacto da conservaço publica 0 exija; quando a casa arde, não nos dirigimos ao juiz para pedir autorização de chama os bombeiros" 64

A esta necessidade prática pode acrescentar se uma interpretação formal. Da expressão "desenvolve e consolida a legalidade" pode deduzir-se um indice deste poder de regulamentação fora de uma regulamentação legislativa. O constituinte moçambicano não emprega somente "consolida" o que poderia levar a crer que devia existir um texto legislativo para fundamentar a sua acçāo porque só é possivel "consolidar" uma causa já existente. Mas o constituinte moçambicano utiliza o termo "desenvolve" que leva a supor que tem a competência de intervir pela sua propria iniciativa fora de um texto legislativo para desenvolver a legalidade que deve ser interpretado aqui como o ordenamento juridico moçambicano

Mas estas interpretações podem ser contestáveis e devem ser apoiadas pela interpretação do artigo 153 da Constituição. Com efeito, 0 artigo 153 é mais explicito que o artigo 152 . Tomemos as alineas e) h) e i) do número 1 par fundamentar a nossa argumentação. A alinea e) do número 1 do artigo 153 precisa "Compete nomeadamente, ao Conselho de Ministros: e) promover e regulamentar a actividade econômi- ca e dos setores sociais". Nesta alinea, o constituinte moçambicano emprega o termo "regulamentar". O Conselho de Ministros pode regulamentar a actividade econômica e a dos setore sociais. Não podemos ser mais explícitos. 0 texto constitucional dá ao Conselho de Ministros a possibilidade jurídica de intervir diretamente preliminar de um texto legislativo. Quais são os setores sociais? A Constituição dá alguns exemplos na sua alinea $h$ ) do número 1 do artigo 153 "os setores sociais do Estado, em especial a edu cação e a saúde". Poderiamos aproximar a alinea h) da i) que está redigida nos seguintes termos: "dirigir e promover a politica de habitacão" que é também um setor social.

Assim, pode-se interpretar esta redação como dando competência ao Conselho de Ministros de regulamentar os setores da educação, da saúde e da habitação. Neste estágio da análise, podemse fazer duas observações. A primeira é referen te ao termo "nomeadamente" no inicio da redação do artigo 153 da Constituição. A segunda abrange a relação "setores sociais" da alinea el do número 1 do artigo 153 e "questões básicas da politica interna e externa do pais". Com efei to, 0 início do artigo 153 precisa "1. Compete nomeadamente, ao Conselho de Ministros..." Isto significa, em primeiro lugar, que os dominié limitado e, por isso, pode estender-se a outras matérias. Se mantivermos esta posição, isso que dizer também que a competência formal que ele detém de regulamentar, essencialmente em vir tude da alínea e) do número 1 do artigo 153 pode estender-se a outros dominios sem que possamos distinguir os limites formais. Aliás, cabe aos setores sociais e a alinea $\mathrm{h}$ ) do numero 1 do artigo 153 emprega o termo "em especial" o que significa que é possivel ao Conselho de Ministros regulamentar outros setores que os da educação, saúde e da habitação.

A segunda observação é relativa à relação das expressōes "setores sociais" da alinea e) do nú mero 1 do artigo 153 e "questões básicas da política interna e externa do país" do número do artigo 135. A aproximação destas duas expressooes realça a possivel concorrência da produção normativa do legislador e do poder regulamentar. Com efeito, como não compreender na locução "questões básicas" os termos "setores sociais"? Os setores sociais estão evidentemente integrados nas questōes básicas da politica interna Assim, pode-se realcar por um lado, a verdadeira concorrência ao nivel da produção normativa, e, por outro lado, o fundamento formal destas competências. Enfim, se os setores sociais são questões básicas, o Conselho de Mi nistros pode regulamentar questōes básicas da política interna e externa do país que não são então, da competência exclusiva do legislador.

Esta interpretação literal do texto constitucional parece estar fortificada pela observação e análise da prática do poder regulamentar na matéria. A exposição de alguns exemplos significativos recentes bastará para demonstrar a adequação entre a carta constitucional e a prática regulamentar.

O primeiro é referente à criacão da Instituição Nacional de Transportes. Após a exposição dos motivos que fundamental a decisão da criação deste organismo, o decreto do Conselho de Ministros expōe o fundamento juridico da sua competência regulamentar: "Nestes termos, ao abrigo da alinea d) do $\mathrm{n}^{0} 2$ do artigo 153 da Constituição da República, o Conselho de Ministros decreta:..."65

O segundo é relativo à criação do Instituto de Cereais de Moçambique ${ }^{66}$. Afim de assegurar a realização concreta da politica do Estado no quadro da promoção e da comercialização dos cereais e de outros produtos agricolas, o poder regulamentar foi levado a criar uma instituição encarregue de "assegurar o fomento da produção e da comercialização de cereais e outros pro-
dutos agricolas, bem como realizar ações que dutos agricolas, bem como realizar ações que
visem garantir a segurança alimentar e a gestão de reservas estratégicas" ${ }^{67}$. O fundamento juridico deste decreto consta na última alinea da exposição dos motivos: "Nestes termos, ao abrigo da alinea el do no 1 do artigo 153 da Constituição da República, o Conselho de Ministros tuição da Rep

O último exemplo68, é relativo à modificação da regulamentação fiscal sobre os combustiveis $^{69}$. Perante a necessidade de proceder a um ajuste das taxas em matéria de combustiveis, Conselho de Ministros adopta um decreto cujo fundamento juridico não faz nenhuma dúvida quanto à sua forma: "no uso das competências conferidas pela alinea e) do artigo 153 da Constituição, decreta:...
Nestes exemplos diferentes, extraidos da prática regulamentar mocambicana, o único fundamento juridico da competencia do au é com certeza o contexto constitucional, essencialmente estas alineas e) do número 1 do artigo $153 \mathrm{e} \mathrm{d)} \mathrm{do} \mathrm{número} \mathrm{2.} \mathrm{Assim,} \mathrm{verifica-se}$ a adequação entre a interpretação literal da Constituição e a prática concreta do poder regulamentar na matéria.

\section{C - Terceira e Última Situação}

O governo adopta um regulamento em qual quer matéria sem que uma lei regule previamente a matéria e o legislador decide intervir na regulamentação desta matéria.

1. Deve-se lembrar previamente, quais os problemas relacionados com a natureza da lei o seu dominio de intervenção - "carácter genérico" e "questões básicas" - que se podem colo-

2. Mas independentemente destes problemas já tratados, é na realidade o problema da hierarquia das normas - lei, deliberação e regulamento - que está em causa. Não é possivel apoiar a teoria do regulamento autónomo porque nenhuma matéria escapa totalmente à competência do legislador. Com efeito, uma das caracteristicas principais dos "regulamentos autónomos" é que o poder regulamentar, de que eles são os vetores formais, exerce-se de modo independente da lei nos dominios que lhe são reservados $^{70}$. O regulamento será superior à lei? A nova lei poderá modificar o regulamento já adoptado?

A meu ver, em direito moçambicano deve adoptar-se uma hierarquia de normas de tipo tradicional e reconhecer à lei ou à deliberação uma autoridade superior a do regulamento. Nesta perspectiva, a lei ou a deliberação podem modificar ou anular um regulamento. A lei mantém-se em relação às regras editadas pelo poder regulamentar a norma superior; "se o regulamento contrariar uma lei, é ilegal"71. A Constituição moçambicana parece orientar-se nesta direção, contudo com uma crítica que diz respeito à redação do texto. Com efeito, 0 artigo 150 da Constituição moçambicana estabelece: "Na sua atuação, o Conselho de Ministros observa as decisões do Presidente da República as deliberaçōes da Assembleia da República"72 
Por outras palavras, este artigo estabelece uma hierarquia das normas; o Conselho de Ministros "observa" - verbo observar, na sua significação de levar a cabo o que está prescrito, o tempo presente, o que quer dizer que é imperativo; o Conselho de Ministros deve observar, deve levar a cabo o que está prescrito - as deliberações da Assembleia da República. Assim, parece estabelecer-se uma hierarquia entre as normas com proeminência da lei ou da deliberação sobre o regulamento. Contudo, deve-se fazer uma observação relativamente ao número 1 do artigo 150 .

Assim, no termo desta demonstração, podemos circunscrever as áreas de acção respectivas do poder legislativo e do poder regulamentar moçambicano.

\section{NOTAS DE REFERÊNCIA}

1 P. Devolve, L'acte administratif, Éd. Sirey, Paris, $1983, n^{0} 281$.

2 D. Freitas do Amaral, Direito administrativo, Vol. III, Lisboa 1989, no 60; M. Caetano, Manual de direito administrativo, Vol. I. Almedina, Coimbra, 1990, no 99 e 193.

3 G. Vedel, e P. Devolve. Droit administratif, Vol. I P.U.F., 12 èd. 1992, p. 279

Sobre exemplos em direito administrativo francês: C.E. 17 de Dezembro de 1948, Azoulay, RDP 1949 p. 76. nota M. Waline; 23 de Maio de 1951. Syndicat intercommunal de Plombières-Les-Dijon, CJEG, 1951 p. 384.

5 "A "usurpaçāo de poder", escreve Diogo Freitas do Amaral, "é o vicio que consiste na prática por um órgão de Administração de um acto incluído nas atribulçōes do poder legislativo ou do poder judicial", Direito administrativo, Vol. III, op. cit., p. 295.

$6 \mathrm{~J}$. Rivero e J. Waline, Droit administratif, Précis Dalloz, 14éme éd., 1992, no 52 e s.; A de Laubadere, Traité de droit administratif, LGDJ, Paris, 1980 not s.: B. Chantebout, Droit constitutionnel et Science politique, A. Colin, Editeur, Paris, 1991, p. administratif Vol. L.: G. Wedel $P 2$. Devolve, Droit admistrau, s. . R. Chapus. Droit administratif 1989, $\mathrm{n}^{\circ} 74$ 6.eme Ed. Montchretien E J A 1992 no 73 ome 7 G. Vedel e P. Devolve, Droit administratif Vol.

cit., p. 25. Ministro dirige a accão do Governo Será responsavel pela defesa nacional. Garantirá a execucão das leis. Sem prejuizo das disposições do artigo 13 , exercerá o poder regulamentar e efetuará nomeaçōes para os postos civis e militares..."
9 B. Chantebout, Droit constitutionnel et science politique, op. cit., p. 377

B. Chantebout, Droit constitutionnel et science politique, idem, p. 378

B. Chantebout, Droit constitutionnel et science politique, ibid., p. 395

2 Trataremos o problema colocado de um ponto de vista exclusivamente jurídico. A questão de sabe se o poder dominante deve ser o poder legislativo ou o poder executivo, se o Parlamento deve limitarse a controlar o Governo ou se deve imiscuir-se na acção governamental e ai tomar iniciativas, "é uma questão politica (M. Hauriou, Precis de Droit Constitutionnel, Ed. Librairie du Recueil Sirey, $2^{\text {eme }}$ ed 1929, p. 383) a qual nos reservamos de responder

Dicionario da Lingua Portuguesa, 7 Éd. Porto Edi-

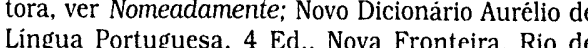
Janeiro, 1976, Ver Nomeadamente.

no no da Assembleia, Resolução $\mathrm{n}^{0}$ 7/91, B.R., 12 de

$15 \mathrm{~J}$. Melo Franco e Antunes Martins,

J. medina, 1993, Ver Deliberação.

16 M. Caetano, Manual de direito administrativo, Vol I, op. cit., $\mathrm{n}^{\mathrm{0}} 93$

Por exemplo, o termo "deliberaçáo" é utilizado para designar a reunião de uma sociedade comercial ao longo da qual é nomeado o Conselho de Administração desta mesma sociedade.

18 Em ultimo recurso, seriamos tentados a aconselha a supressão do termo "deliberação" do texto constitucional que e, sí mesmo, um factor de confusão nào acrescenta nada de concreto aos conceitos jă utilizados pelo constituinte moçambicano.

J.J. Gomes Canotilho, Direito constitucional, $5^{\mathrm{a}} \mathrm{Ed}$. Livraria Almedina, Coimbra, 1992, p. 944

20 J.J. Gomes Canotilho, Direito constitucional, ibid. p. 945.

j.J. Gomes Canotilho, Direito constitucional, idem,
p. 945 .

22 Artigo $172 / 3$ e $224 / 4$.

23 Artigo $172 / 2$ e $229 / 4$.

Artigo $169 / 6,182 / 3$

Artigo 169/5 e 6 . origem das resoluçōes consideradas como constituorigem das resoluçōes consideradas como constitu-
tivas de acto puramente interno do orgão de soberania que as adopta.

27 J.J. Gomes Canotilho, Direito constitucional, ibid., p. 945.

28 J.J. Gomes Canotilho, Direito constitucional, ibid, p. 946 .

29 P. Devolve, Lacte administratif, op. cit., no 149 e s. 30 P. Devolve, Lacte administratif, ibid, $\mathrm{n}^{0} 134$.

1 Por exemplo, ver Moção: Concernente ao agradecimento à deferência de Sua Excelência o Presidente da República e louvor ao Conselho de Ministros, especialmente ao Primeiro-Ministro, B.R., 6 de Janeiro de 1993, I Série - № 1; moçăo: sobre a Le 2 .

Por exemplo, A.R. Resolução no 9/92: Ratifica, na República de Moçambique, a Convenção que ins tui a Agencia Multilateral de Garantias e Investmentos, bem como a adesão de Moçambique a esta Agência, B.R., 25 de Setembro de 1992, I Série № 39

33 Bem como a alinea k) do número 2 do artigo 5 do Regulamento Interno da Assembleia da República.

4 Nesta última hipótese encontra-se o conteúdo orignal da noção entanto que constituindo "um acto puramente interno do órgão de soberania", J.J. Gomes

35 Por exemplo, Resolução no 7/93: Atinente à apreciação pela Assembleia da República da Informação do Governo sobre a Implementação do Acordo Geral de Paz de Mocambique, assinado em Roma a 4 de Outubro de 1992, B.R. de 15 de Junho de 1993 I Série - № 23.

36 O número 1 do artigo 124 da Constituição.

37 J.J. Gomes Canotilho, Direito constitucional, op.

38 J.J. Gomes Canotilho, Direito constitucional, op. cit., p. 946.

39 Moçäo: Concernente ao agradecimento à deferênci de Sua Excelência o Presidente da República e o louvor ao Conselho de Ministros, especialmente ao
Primeiro-Ministro, B.R., 6 de Janeiro de 1993, I Série $-n^{0} 1$.

40 Resolução $\mathrm{n}^{9}$ 7/93: Atinente à apreciação pela As sembleia da República da Informação do Governo sobre a Implementação do Acordo Geral de Paz de Moçambique, assinado em Roma a 4 de Outubro 1992, B.R. 15 de Junho de 1993, I Série - 23 .

1 J.J. Gomes Canotilho, Direito constitucional, op. cit., p. 945

2 Tal controle havia sido desejado pela doutrina poruguesa, Ver, J.J. Gomes Canotilho, Direito consttucional, ibid, p. 945

Entende-se, geralmente, por "genérico" todo termo Eue naire de didaclique des Langues, Libraine Hache,

44 Artigo 180 e a alinea b) do número 1 do artigo 18 da Constituição.

45 Até agora o Conselho Constitucional ainda não fo criado materialmente. Contudo, deve precisar-se que segundo o artigo 202 da Constituição que diz que
"até a entrada em funcionamento do Conselho Consttucional, as suas competências são exercidas pelo Tr bunal Supremo".

46 Assim como, o número 1 do artigo 5 do Regulamento Interno da Assembleia da República. Encontramos a mesma formulaçáo na Constituiçáo de 25 de Junho de 1975, artigo 44 a).
47 Assim como 0 artigo 6 do Regulamento Interno da Assembleia da República.

Sobre o regime das sessôes, ver artigo 7 do Regulamento Interno da Assembleia da República.

Uma exceçáo notável é a do Parlamento Europeu que se reune em sessão anual e conlinua, J. Motade Campos, Direito comunitário, v. I, 6 $6^{\text {eme }}$ ed., Ed. Calouste Gulbenkian, Lisboa, 1989, p. 338 e s.

50 Entenderemos por "poder regulamentar", "o poder de elaborar regulamentos, isto é, de tomar decisōes executórias de carácter geral e impessoal (G. Vedel e P. Devolve, Droit administratif, Vol. I op. cit., p. 326) ou, noutros termos, "a competência atribuída ao poder executivo para editar unilateralmente actos com abrangencia geral (J. Moreau, Droit administratif, op. cli., p. 104), J. Rivero e Walline, Droit adDireito administrativo, Vol UII, op, cit. p. 41 e s. Direlto administrativo, Vol. III, op. cit., p. 41 e s. Amaral, Direito administrativo, Vol. II, idem p. 13 e s. 1 Sob op. cit., p. 18 e s.

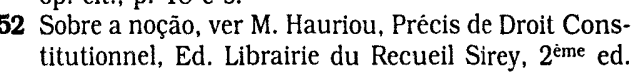
1929 , p. 376 e s.

53 A noção de execuçāo das leis, como lembra Georges Vedel, é muito mais rica do que parece à primeira vista e comporta diversas missões a cargo do poder executivo: a publicação das leis e a chamada de atenção das suas disposiçoes, o emprego da obrigação para assegurar a execuçáo, a execução das leis na realização das tarefas que elas confiam ao Governo, a manutenção da ordem pública e o funcionamento dos serviços públicos. (G. Vedel e P. Devolve, Droit administratif, Vol. I, op. cit., p. 28 e s.)

Sobre a natureza destes regulamentos, ver D. Freias do Amaral, Direito administrativo, Vol. III, op. cit., $\mathrm{n}^{0} 3$ e s; M. Caetano, Manual de direito administrativo, Vol. l, op. cit., $\mathrm{n}$ 44. Por exemplo, no Di 22/92: Define as bases gerais a que obedeca ne 22/ Defne as bas geris a que ober, a 0 trutures encescos de Ders e 1992 I serie $n^{\circ} 53$ é a, B. R., do do sen "Regulamento Bisico", Conselho de Minatros, decreto no 23/93: Aprova 0 Regulamento tros, decto de Outubro de 1993 , I série, no 39 .

55 As alineas b) e c) do artigo 137 da Constituicão as alineas b) e c) do artigo 18 do Regulamento Interno da Assembleia da República.

56 Em virtude do artigo 183 da Constituição.

57 Artigo 180 da Constituição.

58 Ao abrigo do número 1 do artigo 124 da Constituição "Compete ao Presidente da República promulgar e mandar publicar as leis no Boletim da República". 
60 Deve considerar-se a ordem pública na acepção administrativa do termo, isto é como sendo constiuido por um certo minimo de condiçós essenciais para uma vida social conveniente, ver, G. Vedel e P. Devolve, Direito administrativo, Vol. l, op. cit., p. 31.

61 C.C. № 87-149 L. 20 de fevereiro 1987. Rec. 22 62 Ver. M. Long e Al., Les grands arrêts de la jurispru-
dence administrative, $10^{\text {eme }}$ ed., Ėd. Dalloz, 1993, dence administ
p. $183 \mathrm{et} \mathrm{s}$.

630 problema colocava-se em termos diferentes na Constituição de 25 de Junho de 1975 pois a Comissao Permanente da Assembleia Popular podia assegurar a funçáa de Assemblela Popular entre os pe-

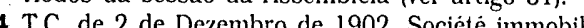

re de St-Just, Rec 713: D.P. 1903.31 , note Hauriou.

65 Decreto $n^{\circ}$ 5/93: Cria o Instituto Nacional de Viaçāo, B.R., 15 de Abril de 1993, I Série - № 15.

6 Decreto no 3/94: Cria o Instituto de Cereais de cambique, B.R., 11 de Janeiro de $1994,2^{\circ}$ Suplemento, I Série - № 1 .

67 Artigo 1 do Decreto no 3/94: Cria o Instituto de Cereais de Mocambique.

68 Poderiamos citar outros exemplos tais como a criacáo do Fundo Nacional do Turismo (Decreto no $10 /$ 93: Cria o Fundo Nacional do Turismo, B.R. 22 de Junho de 1993, 4º Suplemento, I Série - № 24; A modificaçáo dos estatutos do Fundo de Fomento à Pequena Industria aprovados pelo Decreto $\mathrm{n}^{\circ} 3 / 90$, de 12 de Março, B.R., 11 de Janeiro de 1994, Suplemento, I Sćrie - № 1 .
69 Decreto no 8/93: Procede ao ajustamento das taxas constantes da tabela anexa ao Regulamento do Imposto sobre os Combustiveis, B.R., 15 de Junho de 1993, Suplemento, i Série - № 23 .

$70 \mathrm{R}$. Chapus, Droit administratif général, op. cit., $\mathrm{n}^{0}$ 701 e s; D. Freitas do Amaral, Direito administrativo, Vol. III, op. cit., p. 20 e s. e 33 e s.

D. Freitas do Amaral, Direto administrativo, Vol. III, op. cit., p. 17 e 33.

2 Se encontrarmos a mesma formulação na Constituição de 25 de Junho de 1975. Os fundamentos não são exatamente os mesmos. Na Constituição de 25 de junho de 1975, o Presidente da República, embora nomeie o Primeiro-Ministro (a alinea b) do artigo 54), è organicamente diferenciado do Conseho de Ministros (Artigo 59). Na Constituiçáo mosma diferenciono o presidente da República é o "Chefe do Governo" (o numero 3 do artioo 117) 0 fundamento a propria existência do número 1 do artigo 150 só se pode conceber e justificar-se por um desdobra se pode função do órrão presidencial que pode a air como "Chefe do Estado" (Artigo 120), mas tambem como "Chefe do Governo" (Artigo 1211). Na área reservada à actividade do Presidente da República como "Chefe de Estado", o Governo deve "observar" as decisōes do Presidente que não foram tomadas a título de "Chefe do Governo", mas a titulo de "Chefe de Estado".

\section{Reflexões Sobre a Interpretação Literal de Normas no Direito Tributário}

ÍGOR DANILEVICZ

Professor de Direito Tributário da PUCRS e UFRGS. Mestrando em Direito na PUCRS

\section{SUMÁRIO}

1. Introdução; 2. Breves Consideraçōes Sobre a Idéia de Sistema; 3. Sistema x Literalidade; 4. Algumas Decisōes Sobre a Matéria; 5 , Conclusöes.

\section{RESUMO}

O problema da interpretação literal no Direito Tributário. É possivel sua utilização exclusiva em determinados casos apontados na lei? Sistema versus Literalidade. Decisōes sobre a matéria.

\section{ABSTRACT}

The problem of literal interpretation in Law Tax. Is it possible your exclusive utility in any cases indicated in the law? System versus Literal Method. Decisions about the subject.

\section{INTRODUÇão}

A proposta de reflexão - como o titulo está a indicar -, não foi outra do que a fixação do sentido e alcance do disposto no artigo 111 do Código Tributário Nacional - Lei n⿳0 5.172, de 25 10-1966 -, verbis: "Interpreta-se literalmente a legislação tributária que disponha sobre: I suspensão ou exclusão do crédito tributário; II - outorga de isenção; III - dispensa do cumprimento de obrigações tributárias acessórias."

Delimitado o objeto de nossa análise, faz-se imperativo tecer algumas considerações hermenêuticas preliminares. Assim, "a Hermenêutica tem por objeto investigar e coordenar por modo sistemático os principios cientificos e leis decor- rentes, que disciplinam a apuração do conteúdo, do sentido e dos fins das normas juridicas e a restauração do conceito orgânico do direito, para o efeito de sua aplicação: a Interpretação, por meio de regras e processos especiais, procura realizar, praticamente, estes principios e estas leis cientificas; a Aplicação das normas juridicas consiste na técnica de adaptação dos preceitos nelas contidos e assim interpretados às situaçoes de fato que se lhes subordinam."

Considerando a complexidade, a abrangência da vida, e as experiências como um todo devemos interpretar a simbologia posta para interagirmos com o meio e as pessoas. A simbologia aqui, deverá ser entendida na forma mais ampla possivel que a acepção da palavra permita, inclusive o silêncio - eis que até ele se interpreta, como afirma Emilio Caldara ("Interpretare è definire il significato di qualche cosa azione, leggi, contratti, parole, ecc. Tutto si può interpretare e in ogni modo: si interpretano concetti e le intenzione, si interpretano gli indizi, si interpreta anche il silenzio.")2 Nada demasiado termos à mão, alêm da lingüistica, a semiologia juridica.

É neste contexto que será feita a investigação sobre este que é um dos mais debatido enunciados do Sistema Tributário, despertando controvérsias não raro por equivocos na definição dos seus termos. 